\title{
Evolution of structures and fabrics in the Barbados Accretionary Prism. Insights from Leg 110 of the Ocean Drilling Program
}

\author{
JAN H. BEHRMANN
}

Institut für Geowissenschaften und Lithosphärenforschung, Universität Gießen, Senckenbergstr. 3, D-6300 Gießen, F.R.G.

\section{KEvin Brown*}

Department of Geological Sciences, Durham University, South Road, Durham DH1 3LE, U.K.

\section{J. CASey Moore}

Department of Earth Sciences, University of California at Santa Cruz, Santa Cruz, CA 95064, U.S.A.

\author{
Alain Mascle
}

Institut Francais du Petrole, 1-4 Ave Bois-Preau, B.P. 311, 92506 Rueil Malmaison Cédex, France

\section{Elliott TAYlor}

Ocean Drilling Program, Texas A\&M University, 1000 Discovery Drive, College Station, TX 77843, U.S.A.

and

Francis Alvarez (Lamont-Doherty Geological Observatory, Palisades, U.S.A.), Patrick Andreieff (BRGM, Orléans, France), Ross Barnes (Rosario Geoscience Associates, Anacortes, Washington, U.S.A.), Christian Beck (Université de Lille, France), Gerard Blanc (Université Pierre et Marie Curie, Paris, France), Murlene Clark (University of South Alabama, Mobile, U.S.A.), James Dolan (University of California, Santa Cruz, U.S.A.), ANDrew Fisher (University of Miami, Miami, U.S.A.), JoRIS GIESKES (Scripps Institution of Oceanography, La Jolla, U.S.A.), MARK HounsLow (Sheffield University, Sheffield, U.K.), Patrick McLellan (Petro-Canada Resources, Calgary, Canada), KATE Moran (Bedford Institute of Oceanography, Dartmouth, Canada), Yujiro Ogawa (Kyushu University, Fukuoka, Japan), Toyosaburo SaKaI (Utsunomiya University, Utsunomiya, Japan), JANE ScHoONMAKER (Hawaii Institute of Geophysics, Honolulu, U.S.A.), Peter Vrolus (University of California, Santa Cruz, U.S.A.), RoY WILKENS (Massachusetts Institute of Technology, Boston, U.S.A.), ColIN Williams (Lamont-Doherty Geological Observatory, Palisades, U.S.A.)

(Received 2 November 1987; accepted in revised form 26 April 1988)

\begin{abstract}
Detailed analysis of ODP Leg 110 cores provides evidence for a complex structural evolution of the frontal thrust system in the northern Barbados Accretionary Prism. Initial east-directed in-sequence thrusts are biostratigraphically documented, and are overprinted towards the west by out-of-sequence overthrusts, largescale folds and penetrative deformation of the accreted rocks. This structural progression is interpreted to reflect the need for secondary shape adjustments of the accretionary prism in order to maintain a critical taper. At present the basal décollement is located within Lower Miocene strata. Accreted Eocene sediments suggest either fossil frontal off-scraping at a lower stratigraphic level or duplex formation and underplating.

The present localization of the basal detachment is provoked by a zone of initial high porosity in the Lower Miocene radiolarian-rich mudstones. Shearing is accompanied by partial porosity breakdown in a $30-40 \mathrm{~m}$ wide zone of intense scaly fabrics and stratal disruption that constitutes the Atlantic-Caribbean plate boundary at present. Large displacements are taken up by a relatively narrow zone of contact strain. Initially the preferred orientation of clay minerals (incipient scaly fabrics) may be a flattening fabric, but with progressive rotational flow the scaly planes may act as discrete microshears and provide small-scale flow partitioning. Alternatively, scaly fabrics may be interpreted as brittle microshears. Mud-filled veins are present in the accreted rocks as well as at the oceanic reference site east of the deformation front. Carbonate-filled veins are restricted to the accreted rocks. This indicates persistence of high fluid pressures, but a fundamental change in the type of fluid-rock interaction during frontal accretion tectonics.
\end{abstract}

* Present address: Department of Earth Sciences, University of California at Santa Cruz, Santa Cruz, CA 95064, U.S.A. 


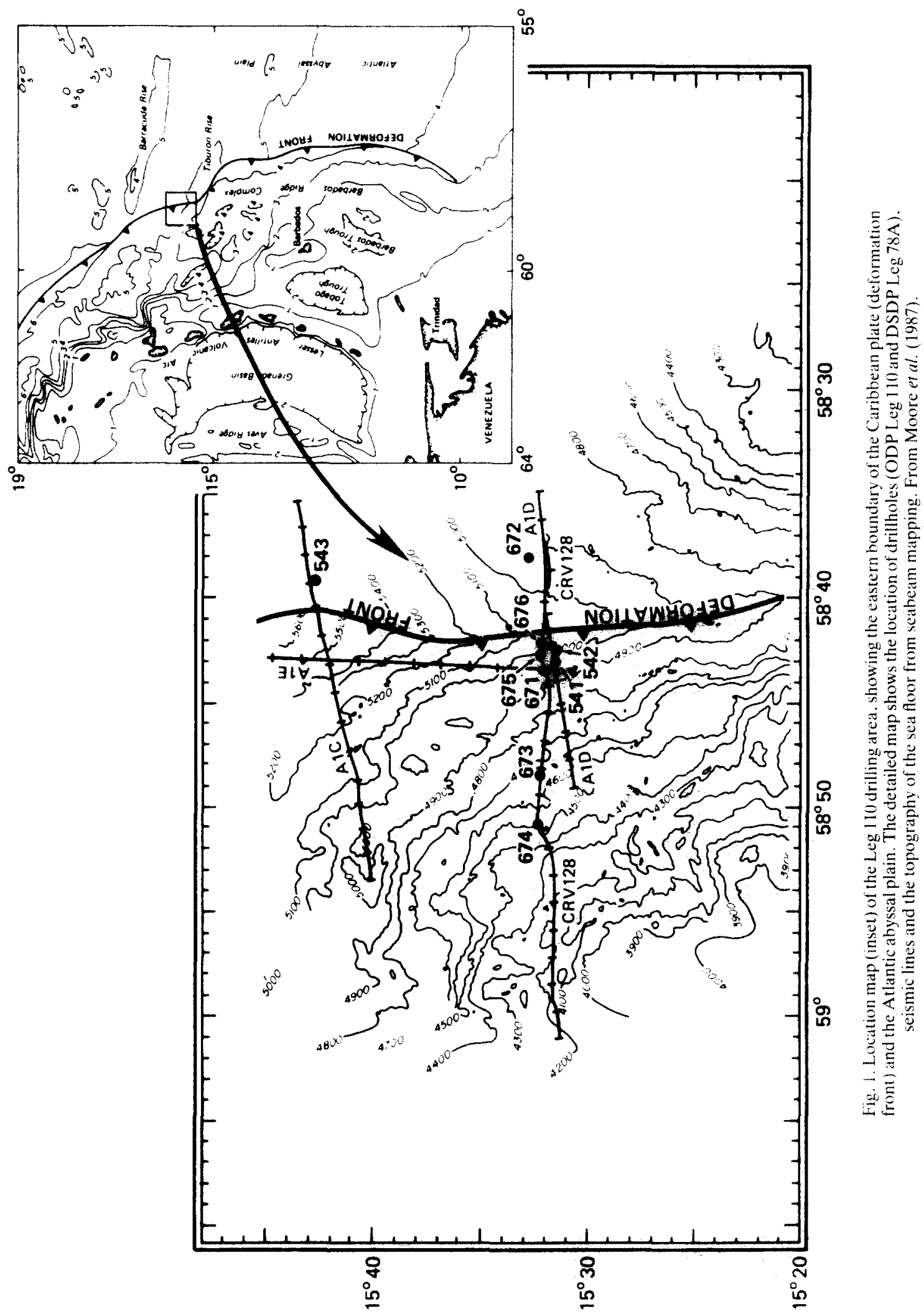




\section{INTRODUCTION}

THE Barbados forearc (e.g. Westbrook \& Smith 1983, Westbrook et al. 1984) is an active accretionary prism to the east of the Lesser Antilles island arc (Fig. 1) and forms the leading edge of the Caribbean plate. The prism is generated by continuous off-scraping of sediment off the west-decending slab of Atlantic lithosphere. The minimum present relative convergence rate between the Atlantic and Caribbean plates is estimated to be east-west at about $2 \mathrm{~cm} /$ year (Sykes et al. 1982, Stein et al. in press). Seismic slip rates suggest slower underthrusting at $0.25-0.5 \mathrm{~cm} /$ year (Molnar \& Sykes 1969 , Dorel 1981). Growth of the prism probably began in Eocene time (Westbrook 1982), although an older origin cannot be disproven.

Seismic reflection profiling across forearc regions provides evidence for considerable deformation of accreted sedimentary sequences (e.g. Silver 1972, Peter \& Westbrook 1976, von Huene 1979, Karig et al. 1980, Westbrook et al. 1982, Aoki et al. 1983, White \& Louden 1983, Valéry et al. 1985). In such a large-scale tectonic framework the study of small-scale tectonic structures can be used to verify seismic interpretations. Additionally over-printing relationships and geometries provide valuable clues for kinematics and mechanisms of accretionary wedge thickening. The positions of thrust zones in boreholes may help elucidate the nature of landward-dipping seismic reflectors (Cloos 1984). Deformation features in the Barbados Accretionary Prism are beautifully exposed on Barbados Island (e.g. Speed 1983) and were also documented in the cores of DSDP Leg 78A (Moore et al. 1982). Leg 110 of the Ocean Drilling Program was located in the vicinity of DSDP Leg 78A sites near the seaward deformation front (Fig. 1) of the prism, to the east of the islands of Dominica and Guadeloupe. In summary, the objectives of Leg 110 with reference to structural geology were:

(1) to achieve a first-ever penetration of the detachment zone between two actively converging plates, and assess the associated deformation;

(2) to provide a complete documentation of the structures found in the toe area of the accretionary prism (Sites 671,675,676; see Fig. 1); and

(3) to determine how structures created at the toe become over-printed towards the rear of the prism during secondary tectonic thickening (Sites 673,674; see Fig. 1).

The pre-accretion reference state of the sediments is reflected by the structures at Site 672, located approximately $5 \mathrm{~km}$ east of the deformation front.

Initial publications on ODP Leg 110 (Mascle et al. 1987, Moore et al. 1987, Gieskes et al. in press) concentrate on hydrological, stratigraphic and geochemical aspects. In this paper we wish to give an account of the shipboard structural analysis of the drillcores, and discuss these initial results in the light of current hypotheses on the deformation of forearc sediments.

\section{LOCAL TECTONIC SETTING}

The drilling area lies to the northeast of the Tiburon Rise (Fig. 1), on an oceanic basement high that is associated with an ENE-trending oceanic fracture zone. The effect of the Tiburon Rise has been to dam the northward flowing Orinoco Fan turbidites. As a result very few turbidites are found to the north of the rise, and sediment thicknesses on the Atlantic plate are reduced from $2-5 \mathrm{~km}$ in the south to $0.4-1.5 \mathrm{~km}$ in the north (Speed et al. 1984). As a consequence, there is a sudden decrease in the dimensions of the accretionary complex north of the Tiburon Rise (Fig. 1) with an associated backstep of the deformation front. Periodicities of accretionary structures are proportional to the thickness of the accreted sedimentary suite (Brown \& Westbrook 1987). As the Leg 110 drilling area is situated on the northern flank of the basement ridge (Fig. 1), the incoming sedimentary section is particularly thin. Therefore the structural grain and initial thrust spacings are anomalously small (generally less than $2 \mathrm{~km}$ ) in comparison with other parts of the complex $(2-5 \mathrm{~km})$ (Belderson et al. 1984, Brown \& Westbrook 1987). Sediments in this region mainly consist of muds, mudstones and marls with minor siltstones and sandstones in the Eocene and Oligocene sections. The sediments were deposited in a pelagic to hemipelagic environment.

Results of seismic investigations (Ngokwey et al. 1984) and DSDP Leg 78A drilling (Moore \& Biju-Duval 1984) suggest that a carbonate-free interval in the early Miocene hosts the basal décollement of the accretionary prism. The thin slope sediment cover (Belderson et al. 1984, Fontas et al. 1984) facilitates drilling into the accreted sequences.

\section{LARGE-SCALE STRUCTURES}

A systematic progression has been documented in the nature and style of the large-scale structures developed during the process of accretion and thickening of the accretionary complex (Figs. 2 and 3 , and seismic section in Fig. 4). However, even before its accretion the incoming section has suffered previous deformational episodes. Good multichannel seismic evidence shows that numerous normal faults were active during the early depositional history of the sediments, being mostly active up to about Lower-Middle Oligocene times (Ngokwey et al. 1984). Some of the normal faults have been more recently active, perhaps in response to flexural bending of the Atlantic plate as it approaches the subduction zone. A number of discrete faults comprising a normal fault zone occur in the reference site (Site 672, see Fig. 2) at about 90-110 m below sea floor. They are spatially associated with a series of mud-filled subvertical veins, some of which show evidence of downdip shearing. Lower in the section (at approximately 180-200 m below sea floor) another set of mud-filled veins is associated with the Lower Miocene sequence. 

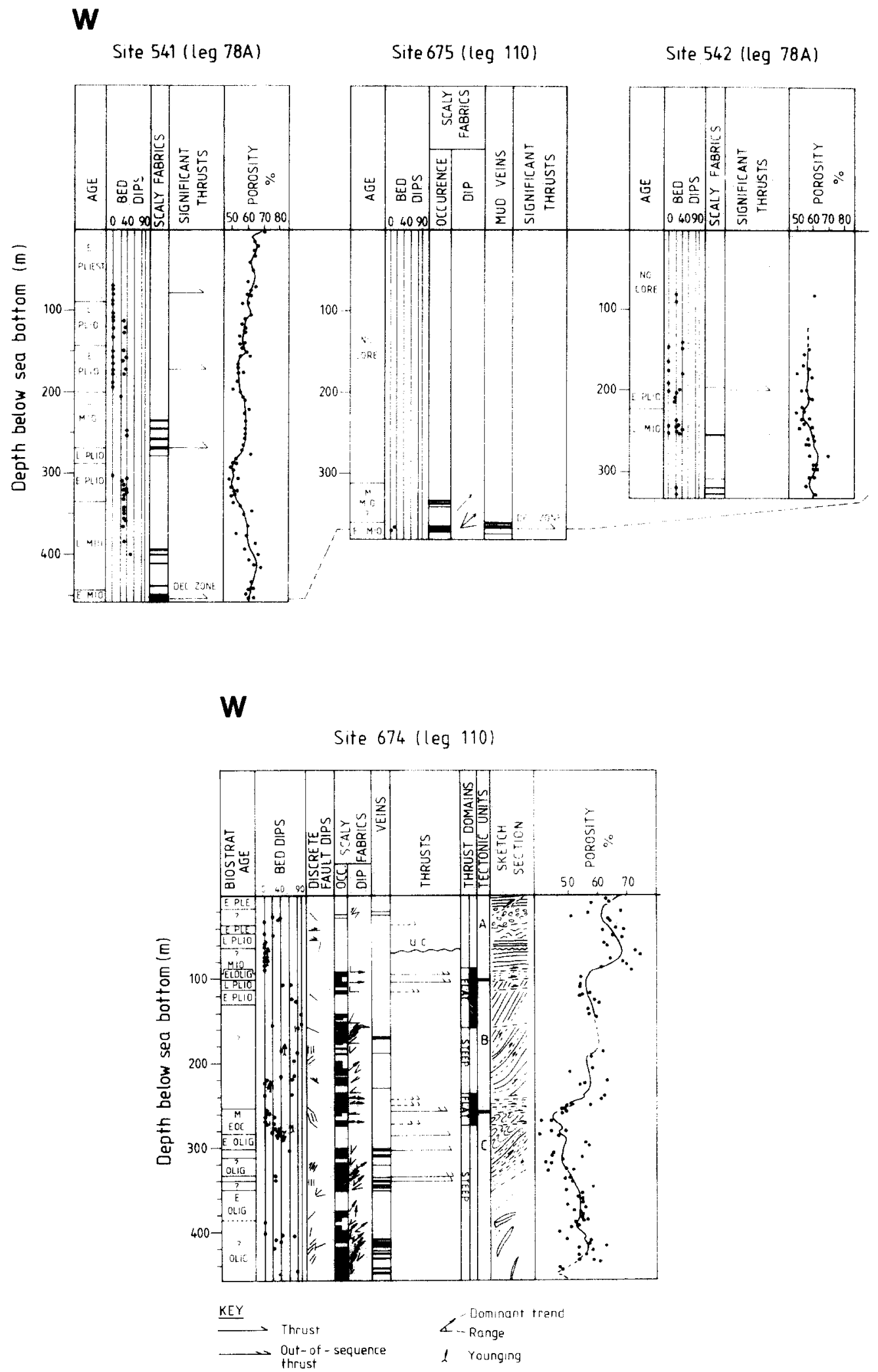

Fig. 2. Composite structural logs of the holes drilled during Legs 78A DSDP and 110 ODP. Site 671B is to the west of Site $54 i$. Note westward increase in structural complexity. 
E

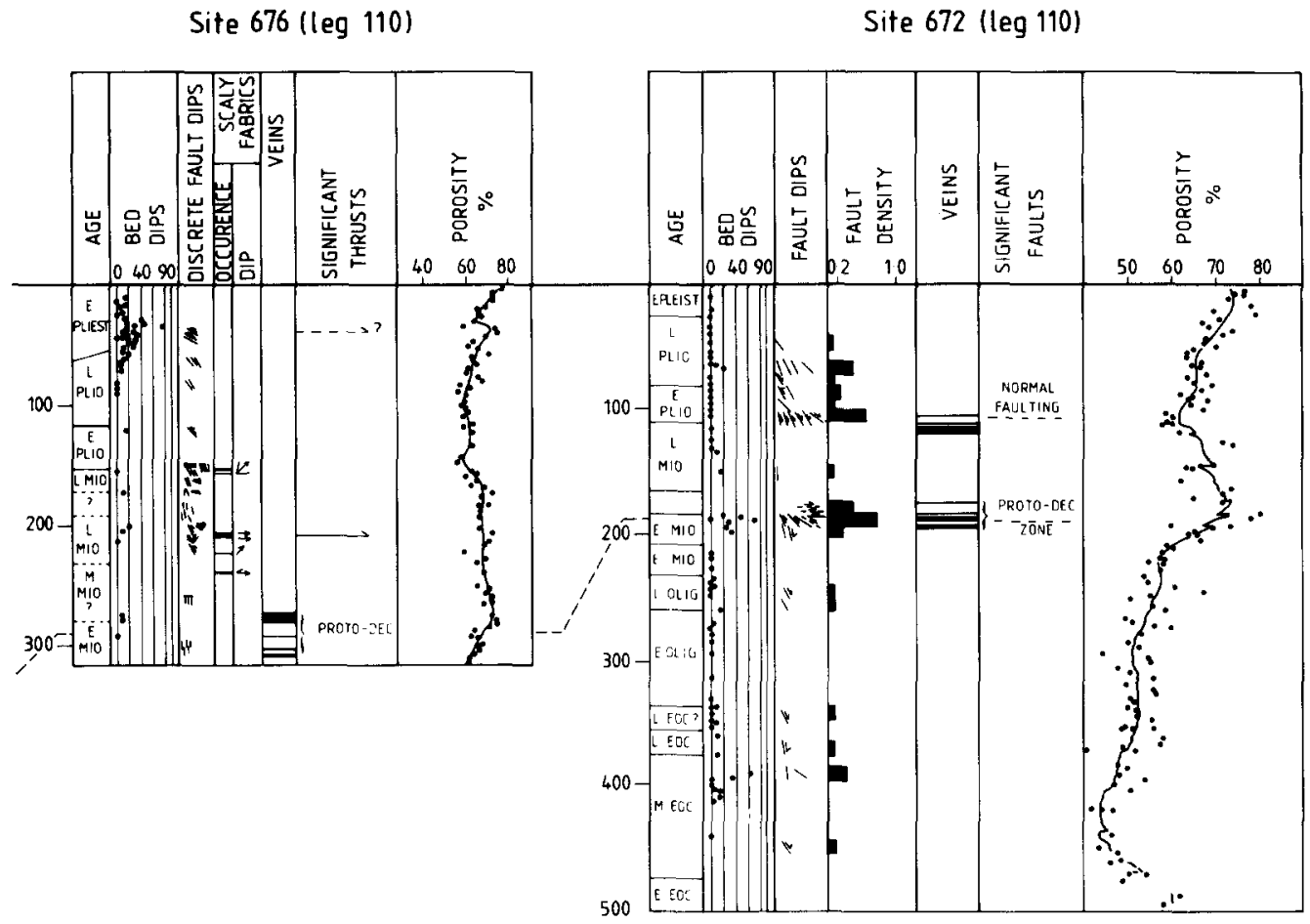

E

Site $673(\operatorname{leg} 110)$

Site 671B (leg 110)

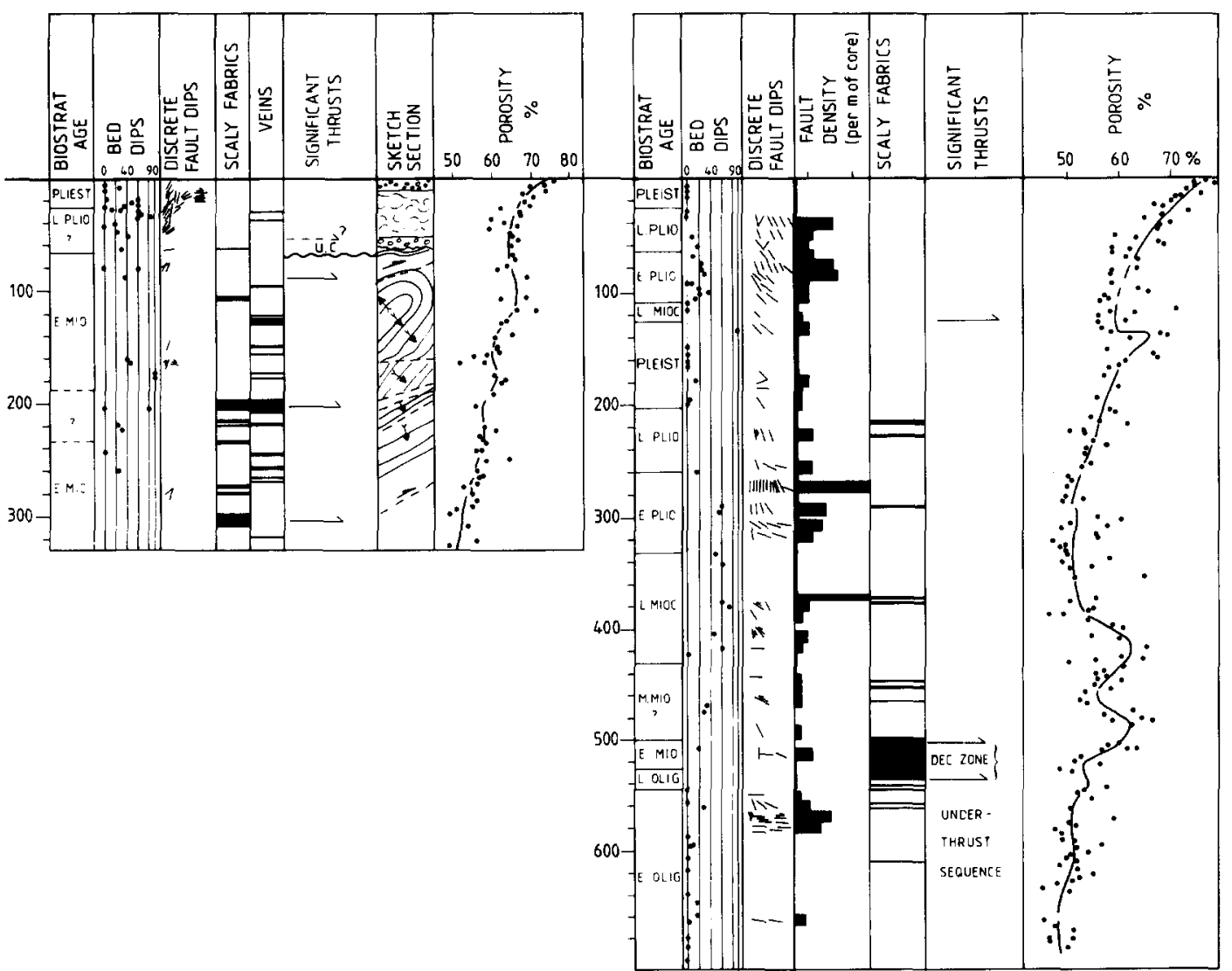

Fig. 2. continued. 


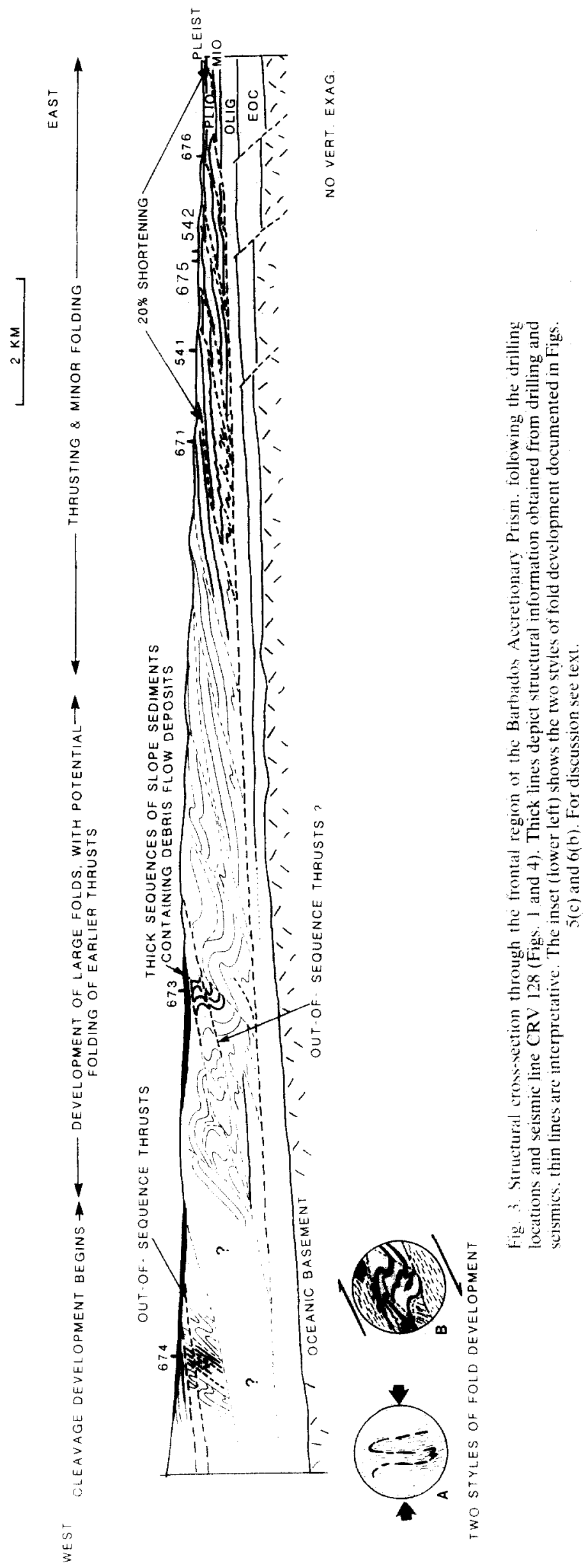




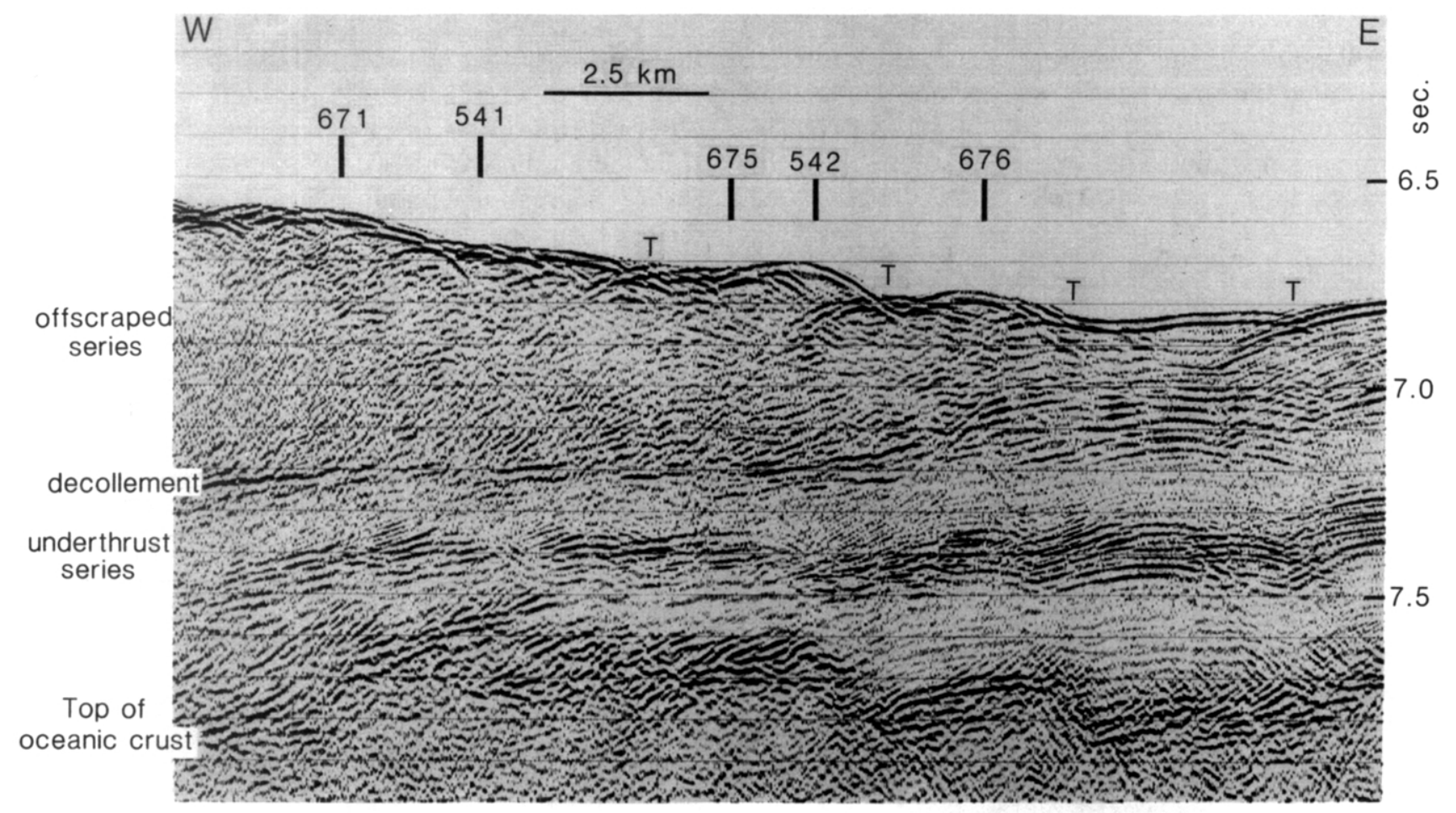

Fig. 4. Seismic section of part of Line CRV 128 (Fig. 1), showing the frontal part of the accretionary wedge, and Leg 78A and Leg 110 drilling locations. Sites 541 and 542 are located approximately $1 \mathrm{~km}$ south of the section. Processing: stack $2400 \%$ and migration. Top of oceanic crust, basal décollement and frontal thrusts ("T" marks their surface outcrops) are clearly visible.

This stratigraphic horizon forms the basal décollement in the frontal part of the accretionary prism further to the west (Figs. 1-3).

The veins are associated with cross-cutting small-scale shear zones and sigmoidal vein sets. Dominant dips of the shear zones and the enveloping surfaces of the vein sets are $0-30^{\circ}$. Displacement vectors associated with the shear zones and sigmoidal vein structures indicate both normal and reverse displacements (Fig. 2), and appear to record the effects of a complicated stress history. This evidence for low-angle shearing cannot be easily explained in the context of high-angle normal faulting. On the contrary, it may be a manifestation of tip strains associated with a propagating detachment as far as $5 \mathrm{~km}$ eastward of the macroscopic deformation front of the accretionary prism. In addition to this, the Lower Miocene 'future décollement horizon' is associated with the base of an anomolously high porosity zone (Fig. 2) and a positive methane anomaly suggesting lateral fluid flow from the accretionary prism (Moore et al. 1987, Gieskes et al. in press).

In the frontal regions of the accretionary complex thrust spacings are in the order of $1-1.5 \mathrm{~km}$ (see Figs. 3 and 4). Thickening dominantly occurs by thrust repetition. On the basis of line-length balancing (Brown et al. in preparation) there is an approximate $20-25 \%$ shortening across the first four to five major imbricate packets (Fig. 3). From area balancing (Brown et al. in preparation) a bulk shortening of more than $50 \%$ can be estimated over the same distance. The implication of the different results obtained by line-length and area balancing methods may be that there is significant distributed deformation not detectable in the seismic sections (small-scale folding, cleavage formation).

Minor folding occurs in the regions just above the major biostratigraphically definable thrusts and the basal décollement (see bed dip logs in Fig. 2). The major thrusts may be associated with small porosity inversions, probably resulting from the emplacement of the older and more compacted sections onto younger sections (see porosity logs in Fig. 2). This inversion is particularly evident for the major thrust (late Miocene over early Pleistocene) in the top of Site 671B (120 m below sea floor).

In general the intensity of small-scale folding increases westward from Sites 676 to 671 . The best evidence for this is the increased variability in bed dips (Fig. 2). However, no overturned sections were identified in the frontal 5-6 km of the complex. A number of zones of scaly clay development occur in each of the Sites between 676 and 671 (see scaly clay logs in Fig. 2). Some are associated with biostratigraphically definable thrusts. Other zones of scaly fabric development that have no definable inversion are interpreted as faults and apparently have vertical throws less than the limits of biostratigraphic resolution $(5-50 \mathrm{~m}$, depending on the stratigraphic horizon). Note that this does not rule out significant subhorizontal displacements.

The basal décollement zone (Figs. 3 and 4) penetrated in the Lower Miocene section at Site 671 is marked by a $40 \mathrm{~m}$ wide zone of scaly clays (Fig. 2) and local stratal disruption. This zone also coincides with lows in 
porosities in Sites 676, 541 and 671 (Fig. 2). Considering that porosities in the Lower Miocene sediments are initially high (Site 672, Fig. 2), we conclude that tectonic deformation causes partial collapse of pore space. This interpretation is supported by earlier studies of microstructures in scaly clays (Moore et al. 1986). Note, however, that local variations in porosity in particular sections are fairly large, and that total overburden and bulk mineralogy affect porosities. It may therefore be meaningful to compare porosity trends, but not absolute numbers.

Occasional minor low angle faulting does occur in the underthrust sequence. Bedding dips are generally horizontal and never exceed $10-20^{\circ}$. Both of these observations indicate that deformation of the underthrust sequence is of very minor importance. There is also very little change in porosity of the underthrust sediments (compare Oligocene sections at Sites 671 and 672 in Fig. 2). This means that the underthrust sequence is not being significantly dewatered at Site 671 in spite of a $300 \mathrm{~m}$ tectonic increase of rock overburden.

There is a significant change both in the stratigraphy of the accreted section and its deformation style between the transect of sites at the toe of the accretionary prism (Sites 676-671B) and Site 673, which is positioned some $12 \mathrm{~km}$ west of the deformation front. The Pleistocene and Pliocene section at the top of Site 673 (Fig. 2) is composed of debris flow deposits and bedded marls, and appears to be of slope origin. The variable dips at the top of the site are in part the result of random block orientations in the debris flows. The bulk of the accreted section is composed of an early Miocene sequence that contains the stratigraphic horizon associated with the basal décollement in the frontal regions of the complex. Thus the basal décollement appears to have been sited at a somewhat lower stratigraphic horizon during this sequence's accretion. Further backward, at Site 674 (Fig. 2), we found accreted strata as old as Middle Eocene with a facies similar to that at Site 672 in the abyssal plain. This suggests that during the accretion of these tectono-stratigraphic packages the basal décollement was located in much older sediments.

The structural style at Site 673 differs from that observed in the more frontal regions of the complex. Good biostratigraphic control (sequences of radiolarian zones) indicates that a large portion of the lower section at Site 673 is inverted, and that a large anticlinal fold (half-wavelength over $100 \mathrm{~m}$ ) occurs within the section (Fig. 2). Porosities across the fold show a steady downward decrease, indicating that the inverted section was further compacted after fold formation.

The greatest change in structural style observed in the complex occurs between Sites 673 and 674. The main differences are the observation of low-angle faults that cut out parts of the stratigraphic section (Fig. 2), abundant carbonate veining and intense scaly fabrics. In addition, stratigraphic units of Oligocene and Eocene age, derived from below the present basal detachment surface in the frontal (Eastern) part of the complex, are present near its surface regions. The low angle faults are interpreted by us as out-of-sequence thrusts for the following reasons: (1) associated seismic reflectors have westward dips; (2) no normal fault scarps can be observed upslope from Site 674; and (3) at a smaller scale there is little evidence for extension, but there are many compressional features (Fig. 2). They are characterized by intense scaly fabric development and have a mixed assemblage of dismembered stratigraphic units in their fault zones. Except for the lowest two out-ofsequence thrusts, the removal of stratigraphic section is associated with large downward decreases in porosity (Fig. 2). This relationship indicates that the out-ofsequence thrusting is essentially young and post-dates most of the compactional history in the accreted sediments. The out-of-sequence structures may correspond to a number of landward dipping reflectors observed on seismic reflection lines across this region of the complex. The porosity-density variation across the structures should give a sufficient acoustic impedance contrast for the thrust zones to be directly imaged as seismic reflectors. The complex has been divided into several tectonic units bounded by the low angle out-of-sequence thrusts (Fig. 2). Within the lower tectonic units bedding, thrust and fabric dips are generally steep.

Steeply dipping thrusts with 'in-sequence' geometries and biostratigraphic relationships are contained within the tectonic units at Site 674. Their present steep dips probably preclude any active displacement along them. Also within the Middle Eocene section at the top of tectonic unit "C" (Site 674, Fig. 2) a number of small (under $10 \mathrm{~m}$ half-wavelength) overturned tight folds occur. Here inversion of beds is documented by crossstratifications and graded bedding. Two styles of fold development were observed in the lower part of Site 674 (see inset on Fig. 3). One style consists of drag features developed in response to shearing along scaly clay zones (Fig. 6b). The other type comprises tight to isoclinal folds with scaly fabrics parallel to the axial surfaces (Fig. 5c; see also later section on fabric development).

\section{SMALL-SCALE STRUCTURES}

Three distinct types of small-scale tectonic structures were encountered in Leg 110 cores: zones of scaly cleavage, brittle faults and veins. We describe each type separately, with reference to the structural logs of the drillholes shown in Fig. 2.

Scaly clays

Scaly clays comprise fissile claystones or hemipelagic muds. Their occurrence has been mentioned in DSDP Leg 78A publications (Moore et al. 1982, Cowan et al. 1984), and they are known from numerous other forearc areas (e.g. Hamilton 1979, Moore \& Karig 1980, Taira et al. 1982). Commonly their origin is attributed to tectonic deformation (e.g. Moore et al. 1986); in our example this is underlined by the good correlation of biostratigraphically defined thrust zones with scaly fabrics (Fig. 2), as 
Structures and fabrics from ODP Leg 110
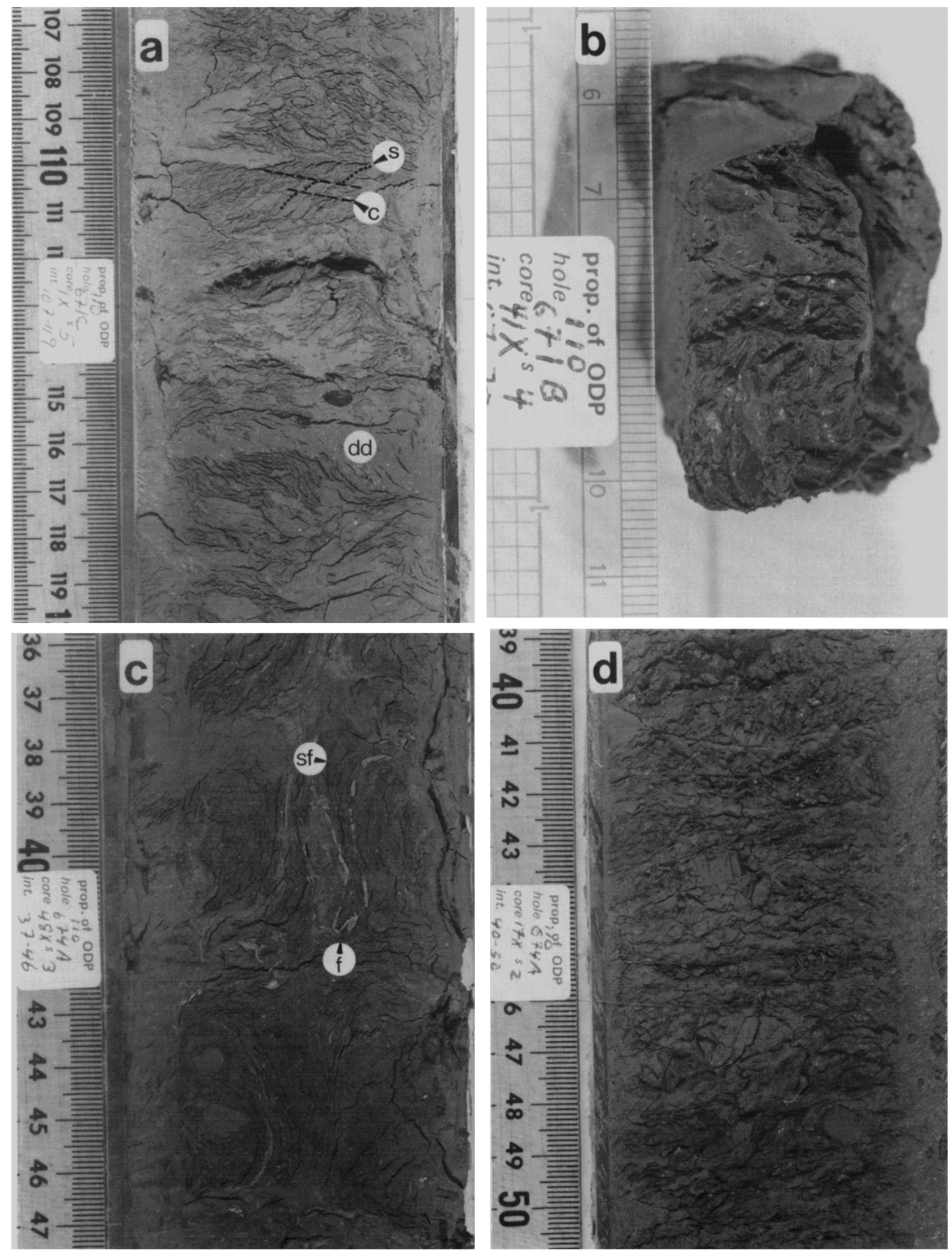

Fig. 5. Close-up photographs of Leg 110 core segments. Scale bars are in centimetres. (a) Scaly fabrics in mudstone of the basal décollement zone (Core $671 \mathrm{C}-1 \mathrm{X}$, section $5,107-119 \mathrm{~cm}$ ). Note local development of $S-C$ type fabrics. The horizontal section designated "dd" is mudstone fluidized during the drilling action ('drilling deformation'). Here the tectonic fabric is obliterated. (b) Scaly fabric surfaces polished by discrete slip. View down core axis (Core 671B-41X, section 4, 67-70 cm). (c) Isoclinally folded (f) veinlet of fibrous calcite with axial planar scaly fabric development (sf) (Core 674A-48X, section 3 , $36-47 \mathrm{~cm}$ ). (d) Stratally disrupted mudstones with scaly matrix and lenticular undeformed clasts (Core 674A-17X, section $2,39-50 \mathrm{~cm})$. 
J. H. Behrmann, K. Brown, J. C. Moore, A. Mascle and E. Taylor et al.
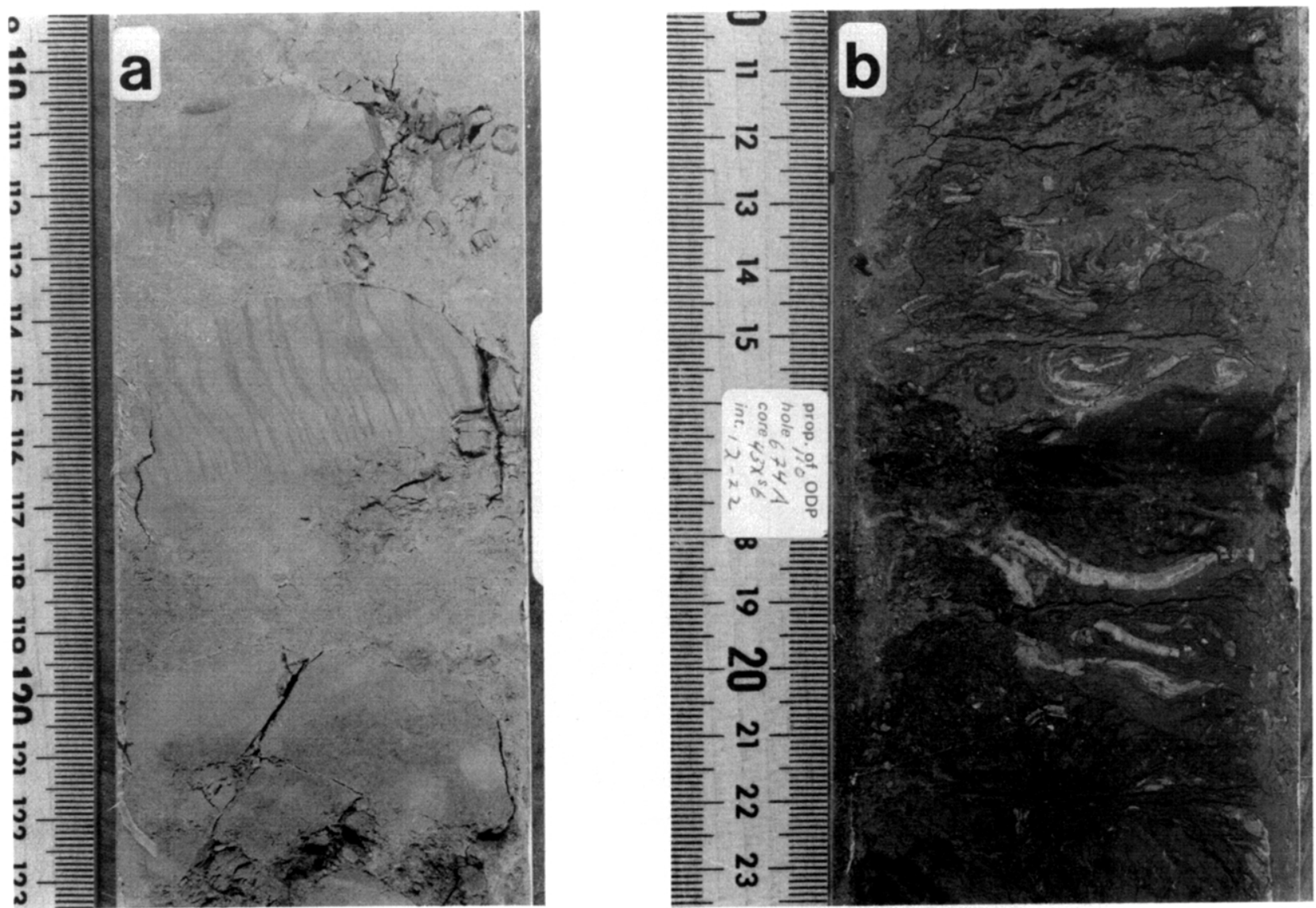

Fig. 6. Two types of vein development. (a) Subvertical mud-filled veins with slight en échelon geometry (arrow). Separation of structurally intact rock into biscuits is drilling deformation (Core 676-30X, section 3, 109-123 cm). (b) Calcite veins in scaly mudstones. Note open folding of some of the veins (Core 674A-43X, section 6, 10-23 cm). 
well as by their absence in the cores of the oceanic reference site (Site 672). The basal décollement zone of the accretionary prism is marked by a $40 \mathrm{~m}$ thick zone of scaly mudstones at Site 671 (Fig. 2). The scaly zones associated with thrust faults within the prism are usually much thinner (between a few millimetres and about $10 \mathrm{~m}$ ). At Site 674, which is located upslope (Fig. 1) scaly fabrics are developed throughout most of the lower part of the cored section, indicating widespread and pervasive deformation of the thrust packets themselves.

The scaly fissility (Fig. 5a) is a mesoscopic expression of a strong preferred orientation of the clay flakelets. When exposed (Fig. 5b) the scaly surfaces are often polished and striated. This indicates their importance as discrete zones of brittle failure and slip. Accordingly they can be interpreted as microshears (e.g. Moore et al. 1986) that would be expected to reflect a local flow plane orientation. There are, however, some observations to suggest that scaly fabrics may not be features of brittle simple shearing alone, but that the spatial relationship with the kinematic framework of deformation may be more complicated. Firstly, scaly fabrics were observed parallel to the axial surface of an isoclinally folded calcite veinlet (Fig. 5c). Secondly, they are found to be oriented parallel to the long axes of clasts in a stratally disrupted mudstone (Fig. 5d). Thirdly, there is local evidence for an overprinting relationship between the scaly fissility and a secondary set of shear surfaces (Fig. 5a), similar in appearance to the shear band or $S-C$ structures (e.g. Simpson \& Schmid 1983, Lister \& Snoke 1984) often observed in mylonitized and strongly anisotropic metamorphic rocks. The closely spaced scaly fabrics are comparable to an $S$-fabric, whereas the smallscale horizontal faults offsetting them are comparable to $C$-surfaces. $S$-fabrics mimic the $X Y$-plane of finite deformation, and $C$-fabrics are usually believed to be parallel to a larger scale shear-zone boundary (e.g. Berthé et al. 1979). Alternatively, in terms of brittle mechanics the secondary shear surfaces could be interpreted as synthetic $\left(R_{1}\right)$ Riedel shears that have been reported from naturally and experimentally produced clay-bearing fault gouges (Rutter et al. 1986).

Dip angles of scaly fabrics were measured in detail at Site 671 across the basal décollement zone of the accretionary prism (Fig. 7). In published seismic sections (Westbrook et al. 1984) the décollement appears as an almost horizontal feature, but dip angles of the fabric of less than $10^{\circ}$ are exceedingly rare, and those between 10 and $25^{\circ}$ are the rule. The same is true for scaly cleavage dips in the décollement zone at Site 675. This difference between the orientations of scaly fabrics and the basal décollement may be interpreted in a number of ways.

(1) Scaly fabrics originate as flattening features (Fig. $8 \mathrm{a})$. In this case orientations will become shear-zone parallel only if strains are very high. Variations in dip reflect strain variations that may result in $S-C$ fabrics as depicted in Fig. 8(b). Progressive asymptotic rotation also opens the possibility that scaly fabrics become discrete zones of slip, as the resolved shear stresses along them are increased (Fig. 8c). This may explain why a lot

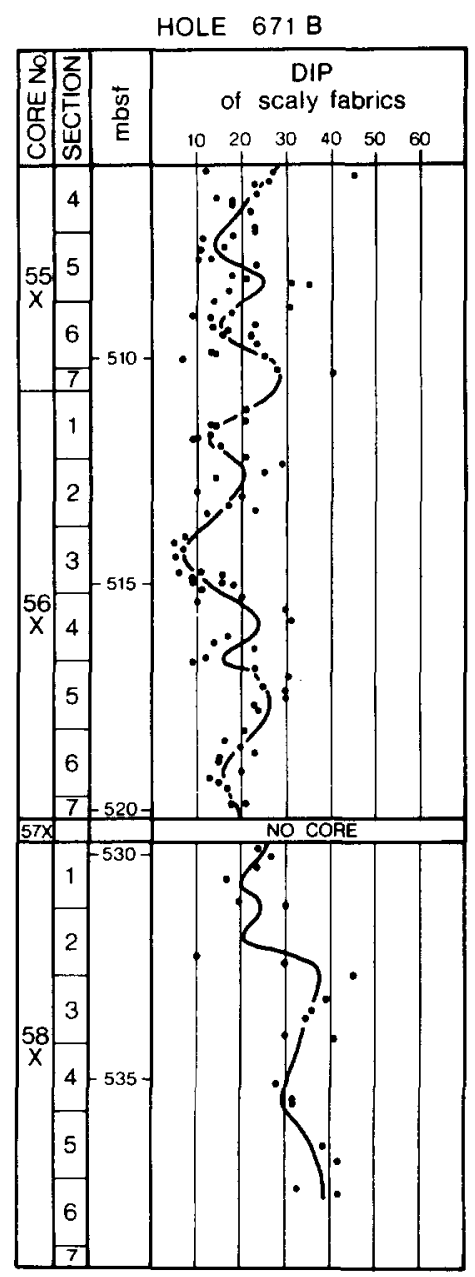

Fig. 7. True dip angles of scaly fabrics across the basal décollement zone in Site 671B.

of the scaly surfaces are found to be striated and polished (Fig. 5b). Discrete slip in the later part of the strain history means flow partitioning (Fig. 8c), which may encompass any combination of simple shear, coaxial stretching and rigid body rotation (see e.g. discussions by Lister \& Williams 1983 or Platt 1984).

(2) The scaly fabrics could be folded. Local evidence for this comes from the décollement zone at Site 541.

(3) The scaly fabrics could be rotated out of a flow plane parallel orientation by microduplex formation. This model is advocated by Platt et al. (in press, fig. 14) to explain gouge fabric formation in the Makran Accretionary Prism.

In case (1), scaly fabrics would have to originate as strain-dependent flattening features, irrespective of later flow partitioning. Cases (2) and (3) leave open the possibility that scaly fabrics are normal stress-dependent brittle shear fractures. The data presented here can only serve to illustrate a current debate. Careful microstructural work might provide a definite answer.

\section{Discrete faults}

Measured dip angles and frequencies of small-scale brittle faults are displayed in the structural logs in Fig. 2. 


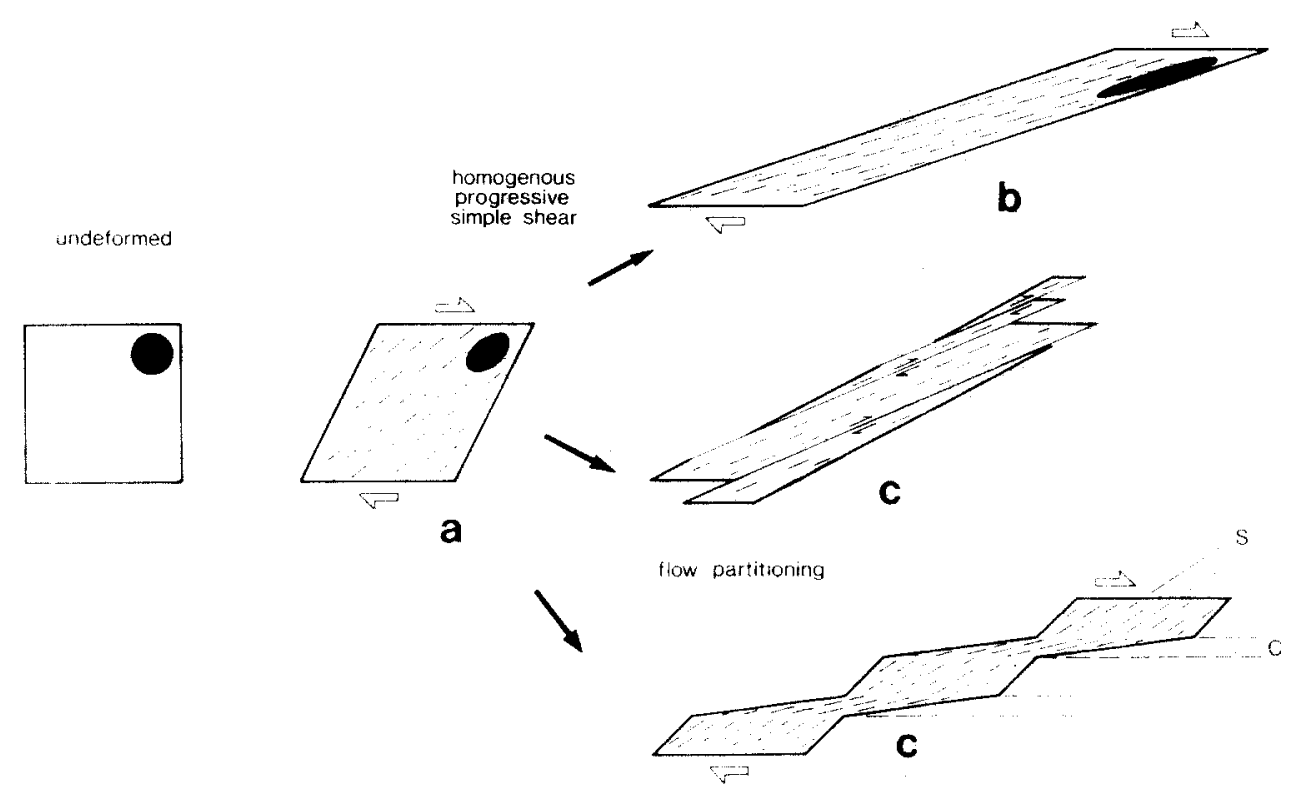

Fig. 8. Model for progressive scaly fabric evolution. An undeformed reference cube is deformed in plane strain involving different flow paths and geometries. (a) Initial generation of scaly fabrics at high angle to the shear plane parallel to the $X Y$ plane of finite deformation. (b) Progressive homogeneous simple shear with rotation of scaly fabrics towards the shear plane. (c) Sketches of two different modes of flow partitioning. The upper one depicts discrete slip on scaly surfaces plus homogeneous simple shear. The lower one is heterogeneous simple shear and generates $S-C$ fabrics.

Here we speak of mesoscopic faulting with clearly visible truncations and offsets of primary markers in the core (sedimentary beds, burrows, etc.). Wherever resolved, the kinematic nature of the faults is denoted by the small associated arrows indicating the shear senses. Perhaps the most interesting pattern of brittle faulting is encountered in Site 671B (Fig. 2). Fault geometries in the upper part of the sediment sequence are mostly steep, with a predominance of normal faults on top of the uppermost thrust, and reverse faults below it. In this context 'normal' and 'reverse' signifies the down-dip components of the slip vectors. Low angle faults are common in sediments below $300 \mathrm{~m}$ sub-bottom. Note that fault densities are highest within the individual thrust sheets, and that the scaly movement zones coincide with low fault densities. This brittle fault distribution points out a possibly important contrast in rheology between the interiors of thrust slices (brittle; Coulomb type behaviour) and the movement zones (ductile; viscous or plastic flow). Where encountered, conjugate sets intersect at angles of about $60^{\circ}$, indicating that coefficients of friction for faulting of the soft mudstones are somewhat lower than those of fully lithified crustal rocks (e.g. Byerlee 1977).

\section{Vein development}

Two main types of veins will be concentrated on in this paper: mud-filled veins and calcite veins. Mud-filled veins have been encountered in several active margin settings, and their origin has been discussed by Arthur et al. (1980), Cowan (1982), Ogawa \& Miyata (1985), and more extensively by Lundberg \& Moore (1986) and Knipe (1986). In our case the veins are steeply dipping dilatant features (Fig. 6a), and their common sigmoidal form suggests that they are associated with low angle shearing. At the reference site $(672$, Fig. 2) they are linked with the two well-defined fault zones, indicating their tectonic origin. However, note that a mud-filled vein is not necessarily a feature restricted to preaccretion deformation.

Millimetre to centimetre thick carbonate veins (Fig. 6b) are restricted to the accreted sediments. The carbonates mostly consist of fibrous or non-fibrous calcite, but in one case rhodochrosite was documented as the vein-filling material. The spatial correlation of carbonate veins with horizons of scaly fabrics is good (Fig. 2). With reference to scaly fabric formation they may be pre-tectonic (see the folded examples in Figs. $5 \mathrm{c}$ and $6 \mathrm{~b}$ ), or post-tectonic. The carbonate fills suggest that the zones of scaly fabrics in the accreted sediments were at least episodically loci of high fracture permeability, In contrast to the mud-filled veins they present a clear proof of mass transfer and deposition of previously dissolved matter. Their presence may be critical for the understanding of the close link between active thrust faulting and low chlorine-high methane interstitial waters (Moore et al. 1987, Gieskes et al. in press) in rocks that often have lower porosities than their undeformed counterparts (see discussion above).

\section{DISCUSSION}

The interpretation of the data presented raises some interesting points about the mechanics of the basal décollement zone of accretionary wedges in general, and of the Barbados case in particular. Initial localization of displacement in the radiolarian-rich mudstones of early Miocene age is best explained by their high porosities 
(Site 672, Fig. 2), giving them a comparatively low shear strength. The high porosities may be a primary sedimentary feature, or alternatively they may be created by high pore fluid pressures prior to deformation. However, once there is sizeable deformation in the décollement (Fig. 2, Sites 676, 541 and 671B) porosities are distinctly lower than those of the immediate wall rocks.

In principle, pore space collapse should result in a better ability of the rocks to sustain shear stresses; i.e. strain hardening (Karig 1986, Moore et al. 1986) and relocation of the zone of yielding elsewhere. The presence of slickensided scaly surfaces and veins indicates that there is mesoscopic shear and tensile failure. Scaly surfaces in easy slip orientations (geometric softening) and veins (high pore fluid pressures) may explain why strain and displacement are efficiently concentrated within the zones of scaly fabrics. In cases where the scaly fabric has low-angle dips (Fig. 7), high shear stresses are resolved on basal interfaces of clay minerals, and there may be easy microscopic intergranular slip. However, in a regime of subhorizontal compression such a model does not explain strain localization in the numerous zones within the accreted sequences where scaly fabric dips are steep.

The presence of Oligocene and Eocene age rocks towards the rear of the accretionary prism indicates that the stratigraphic position of the basal décollement either has not been stable through time, or cuts up section from a lower stratigraphic level somewhere towards the rear of the prism at present. One possibility to explain this is fossil frontal accretion of Eocene-Oligocene rocks in the form of an imbricate stack (Fig. 9a). The alternative would be large-scale young duplex formation and underplating at depth in the accretionary prism (Fig. 9b). This phenomenon was in fact identified in seismic sections further south (line $\mathrm{L}^{-\mathrm{L}^{\prime}}$ in Speed et al. 1984) in the Barbados Accretionary Prism.

\section{a}

w

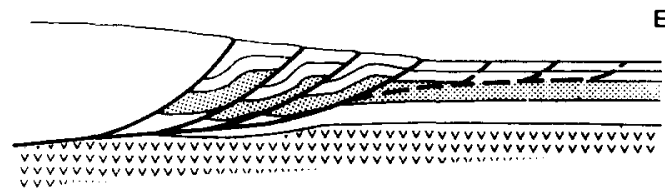

b

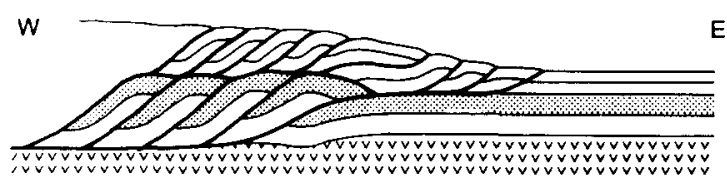

Fig. 9. Two models to explain the incorporation of Eocene and Oligocene rocks into the Barbados Accretionary Prism. Not to scale. (a) Time-dependent jump of the décollement level. Dashed lines represent future thrusts. "V" signature depicts basaltic oceanic crust. (b) Underplating of Eocene-Oligocene by duplex formation at depth in the accretionary prism. Note that these thrust systems have to be completed by adding out-of-sequence thrusts.
Other key observations are the out-of-sequence overthrusts documented at Site 674 (Fig. 2). Their importance in the definition of accretionary wedge shapes was stressed by Moore et al. (1985), and their presence gives evidence that in the Barbados case the progressive westward thickening of the accretionary prism may not be dominantly achieved by rotation and steepening-up of the thrust packets (Karig \& Sharman 1975). In the light of limited back-rotation of thrust slices, out-of-sequence thrusting is geometrically necessary to maintain the critical taper of the accretionary wedge. Out-ofsequence thrusting also means that deformation histories may be quite complex even in the early stages of sediment accretion.

The occurrence of Oligocene strata high in the section at Site 674 (Fig. 2) documents that part of the top of the thrust sequence must have been eroded before the deposition of the slope sediment debris flows. Possible causes for oversteepened surface slopes necessary for sub-aquatic erosion in the form of turbidites or mass flows are either out-of-sequence thrusts or underplating with duplex formation at depth.

Interesting inferences about the age of structures can be made by comparing the structural and porosity data in Fig. 2. As discussed above, young and active thrusts near the deformation front are characterized by porosity inversions. In contrast we observe an approximately undisturbed porosity profile across the $100 \mathrm{~m}$ scale fold at Site 673, indicating that significant parts of the compactional history in these rocks are younger than the folding. The degree of compaction here reflects the degree of post-tectonic loading, and not necessarily the degree of deformation. The out-of-sequence thrusts at Site 674 are associated with discontinuous downward decreases in porosity, suggesting young or recent displacements along these structures. Porosity logs at Sites 673 and 674 are not disturbed across the biostratigraphically documented in-sequence thrusts, indicating that these structures have probably been inactive for some time. The documented breaks in physical properties of the accreted sediments and their good correlation with tectonic structures also speaks against the interpretation of landward-dipping seismic reflectors as changes in acoustic impedance only related to circulation of fluids (Cloos 1984). This does not preclude active fluid circulation along some of the faults (as documented by Moore et al. 1987 or Gieskes et al. in press), but it is probably petrophysical contrasts and not fluid content that creates the seismic reflections.

\section{CONCLUSIONS}

(1) The frontal region of the Barbados Accretionary Prism shows a polyphase structural evolution that may serve as a test-case for the frontal deformation of orogenic wedges. Initial in-sequence overthrusting is overprinted by secondary wedge thickening in the form of out-of-sequence thrusting, large-scale folding and penetrative deformation. 
(2) At present the basal décollement of the accretionary wedge is located within mudstones of early Miocene age. Accreted rocks as old as Eocene indicate time-dependent variations in the stratigraphic level of detachment, or large-scale duplex formation and underplating.

(3) Unexpected evidence for subhorizontal shearing in the lower Miocene 'future décollement horizon' was found as far as $5 \mathrm{~km}$ east of the deformation front. Associated structures may represent the tip strains of a propagating detachment.

(4) Scaly fabrics are linked to tectonic deformation, and in some cases reflect zones of large thrust displacements. The data and observations presented here leave open possibilities to interpret scaly fabrics as brittle microshears, or as ductile phenomena. A more definite answer may be provided by microstructural studies.

(5) The comparison of porosity data and structural features provides interesting insights into the relation between the compaction and deformation histories. Active thrusts are associated with abrupt downward increases of porosity. Across fossil structures the degree of compaction seems to be principally depth-dependent.

Acknowledgements-We are grateful for the support of the ODP Technical, Operations and Engineering groups, and SEDCO personnel who were instrumental in obtaining the data reported here Lamar Hayes of ODP and Bob Caldow of SEDCO supervised the drilling program that achieved penetration of the décollement zone The Ocean Drilling Program is sponsored by the National Science Foundation, the European Science Foundation, and national institutions in Canada, Federal Republic of Germany, France, Great Britain and Japan. Comments of J. Platt, R. Knipe, S. Treagus and an anonymous referee on earlier versions of this manuscript were most helpful.

\section{REFERENCES}

Aoki, Y., Tamano. T. \& Kato, S. 1983. Detailed structure of the Nankai trough from migrated seismic sections. In: Studies in Continental Margin Geology (edited by Watkins, J. S. \& Drake, C. L.). Mem. Am. Ass. Petrol. Geol. 34, 307-322.

Arthur, M. A.. Carson, B. \& von Huene, R. 1980. Initial tectonic deformation of hemipelagic sediment at the leading edge of the Japan convergent margin. Init. Reps DSDP. Washington (U.S. Govt Printing Office), 56/57, 568-615.

Belderson, R. H., Kenyon, N. H. \& Stride, A. H. 1984. Morphology and structural trends of the Barbados Ridge Complex in the vicinity of Deep Sea Drilling Project Sites 541, 542 and 543 as revealed by Gloria long-range side-scan sonar. Init. Reps DSDP. Washington (U.S. Govt Printing Office), 78A, 79-81.

Berthé, D., Choukroune. P. \& Gapais, D. 1979. Orientations préférentielles du quartz et orthogneissification progressive en régime cisaillant: l'exemple du cisaillement sud-armoricain. Bull. Minéral. 102, 265-272.

Brown, K. M. \& Westbrook, G. K. 1987. The tectonic fabric of the Barbados Ridge accretionary complex. Mar. Petrol. Geol. 4, 71-81.

Brown, K. M., Behrmann, J. H. \& Mascle. A. In preparation Balanced sections across the toe of the Barbados Ridge Complex Proc of the Ocean Drilling Program, $110 \mathrm{~B}$.

Byerlee. J. D. 1977. Friction of rocks. In: Experimental Sudies of Rock Friction with Application to Earthquake Prediction (edited by Evernden, J. F.). U.S. Geol. Survey, Menlo Park, 55-57.

Cloos, M. 1984. Landward-dipping reflectors in accretionary wedges active dewatering conduits? Geology 12, 519-522.

Cowan. D.S. 1982. Origin of 'vein structure' in slope sediments on the inner slope of the Middle America Trench off Guatemala. Init. Reps DSDP, Washington (U.S. Govt Printing Office), 67. 645-650.

Cowan. D. S.. Moore. J. C. Roeske, S. M., Lundberg. N. \& Lucas.
S. E. 1984. Structurat features at the deformation front of the Barbados Ridge Complex. Deep Sea Drilling Project Leg 78A. Init. Reps DSDP. Washington (U.S. Govt Printing Office), 78A, 535548 .

Dorel, J. 1981. Seismicity and seismic gap in the Lesser Antilles arc and earthquake hazard in Guadeloupe. Geophys. J. R. astr. Soc. 67, 679-695.

Fontas, P. . Valéry. P., LeQuellec, P., Mascle, A., Renard, V., Tardy, M. \& Biju-Duval, B. 1984. Multibeam bathymetric survey of the Leg 78A drilling area and comparison with the southern part of the Barbados Ridge deformation front. Init. Reps DSDP. Washington (U.S. Govt Printing Office), 78A, 63-78.

Gieskes, J., Blanc, G., Vrolijk, P., Moore, J. C., Mascle, A.. Taylor, E., Andreieff, P., Alvarez, F., Barnes, R., Beck, C., Behrmann, J. Brown, K., Clark, M. Dolan. J., Fisher, A., Hounslow, M., McClellan, P., Moran, K.. Ogawa. Y.. Sakai, T., Schoonmaker, J., Wilkens, R. \& Williams, C. In press. Hydrogeochemistry in the Barbados Accretionary Complex. Tectonophysics.

Hamilton, W. 1979. Tectonics of the Indonesian region. U.S. Geol Survey Prof. Paper. 1078.

Karig, D. E. \& Sharman, G. F. 1975. Subduction and accretion in trenches. Bull. geol. Soc. Am. 86, 377-389.

Karig, D. E. 1986. Physical properties and mechanical state of accreted sediments in the Nankai. Trough, Southwest Japan Arc. Mem. geol. Soc. Am. 166, 117-133.

Karig, D. E., Moore, G. F. Curray, J. R. \& Lawrence, M. B. 1980. Morphology and shallow structure of the lower trench slope off Nias Island, Indonesia. In: Tectonic and Geologic Evolution of Southeast Asian Seas and Islands (edited by Hayes, D. E.). Am. Geophys. Union Geophys. Monogr. 23, 179-208.

Knipe, R. J. 1981. The interaction of deformation and metamorphism in slates. Tectonophysics 78.249-272

Knipe, R. J. 1986. Microstructural evolution of vein arrays preserved in Deep Sea Drilling Project cores from the Japan Trench, Leg 57. Mem. geol Soc Am. 166, 75-87.

Lister, G. S. \& Williams. P. F. 1983. The partitioning of detormation in flowing rock masses. Tectonophysics 92, 1-33.

Lister, G. S. \& Snoke. A. W. 1984. S-C mylonites. J. Struct. Geol. 6. $617-638$.

Lundberg, N. \& Moore. J. C. 1986. Macroscopic structural features in Deep Sea Drilling Project cores from forearc regions: $\mathrm{Mem}$. geol. Soc. Am. 166, 13-44.

Molnar, P. \& Sykes. L. R. 1969 . Tectonics of the Caribbean and Middle America regions from focal mechanisms and seismicity. Bull. geol. Soc. Am. 80, 1639-1684.

Mascle, A., Moore, J. C.. Taylor, E.. Alvarez, F., Andreieff, P., Barnes, R., Beck, C., Behrmann, J., Blanc, G., Brown, K., Clark, M., Dolan, J.. Fisher. A., Gieskes, J., Hounslow, M. . McClellan, P., Moran, K. Ogawa, Y. Sakai. T.. Schoonmaker, J., Vrolijk, P. Wilkens, R. \& Wiltiams, C. 1987. Accretionary complex penetrated, defined. Geotimes 1987(1), 13-16.

Moore. G. F. \& Karig. D. E. 1980. Structural geology of Nias Island, Indonesia: implications for subduction zone tectonics. Am. J. Sci. 280, 193-223.

Moore. J. C.. Biju-Duval. B., Bergen. J. A., Blackington. B., Claypool, G. E., Cowan, D. S., Duennebier. F.. Guerra, R. T., Hemleben, C. H. J. Hussong, D., Marlow, M. S. Natland, R. H., Pudsey, C. J. . Renz, G. W. Tardy, M., Willis, M. E. Wilson, D. \& Wright, A. A. 1982. Offscraping and underthrusting of sediment at the deformation front of the Barbados Ridge: Deep Sea Drilling Project Leg 78A. Bull. geol. Soc. Am. 93, 1065-1077.

Moore. J. C. \& Biju-Duvat, B. 1984. Tectonic synthesis, Deep Sea Drilling Project Leg 78A: structural evolution of offscraped and underthrust sediment, Northern Barbados Ridge Complex. Init. Reps DSDP. Washington (U.S. Guvt Printing Office), 78A, 601621

Moore, J. C., Cowan. D. S. \& Karig. D. E. 1985. Structural styles and deformation fabrics of accretionary complexes. Geology 13, 77-79.

Moore, J. C., Roeske. S.. Lundberg, N., Schoonmaker. J., Cowan. D. S.. Gonzales, E. \& Lucas, S. E. 1986. Scaly fabrics from Deep Sea Drilling Project cores from forearcs. Mem. geol. Soc. Am. 166 , $5.7-73$.

Moore. J. C. Mascle, A.. Talylor, E., Alvarez, F.. Andreieff, P. Barnes, R., Beck, C. Behrmann, J. B Blanc, G. , Brown, K., Clark. M., Dolan, J., Fisher, A.. Gieskes, J., Hounslow, M. . MeClellan, P.. Moran, K. Ogawa, Y., Sakai, T., Schoonmaker, J., Vrolijk, P. J. Wilkens, R. \& Williams. C. 1987. Expulsion of fluids from depth along a subduction-zone decollement horizon. Nature 326, 785-788. Ngokwey. K., Mascle. A. \& Biju-Duval. B. 1984. Geophysical setting 
of Deep Sea Drilling Project Sites 541, 542 and 543. Init. Reps DSDP, Washington (U.S. Govt Printing Office), 78A, 39-48.

Ogawa, Y. \& Miyata, Y. 1985. Vein structure and its deformational history in the sedimentary rocks of the Middle America trench slope off Guatemala, Deep Sea Drilling Project Leg 84. Init. Reps DSDP, Washington (U.S. Govt Printing Office), 84, 811-829.

Peter, G. \& Westbrook, G. K. 1976. Tectonics of the southern North Atlantic and Barbados Ridge complex. Bull. Am. Ass. Petrol. Geol. 60, 1078-1106.

Platt, J. P. 1984. Secondary cleavages in ductile shear zones. J. Struct. Geol. 6, 439-442.

Platt, J. P., Leggett, J. K. \& Alam, S. In press. Slip vectors and fault mechanics in the Makran Accretionary Wedge, southwest Pakistan. J. geophys. Res. 92.

Rutter, E. H., Maddock, R. H., Hall, S. H. \& White, S. H. 1986. Comparative microstructures of natural and experimentally produced clay-bearing fault gouges. In: Natural and Experimental Studies of Fault Rocks (edited by Wang, C. H.). Pure \& Appl. Geophys. 124, 3-30.

Silver, E. A. 1972. Pleistocene tectonic accretion of the continental slope off Washington. Mar. Geol. 13, 239-249.

Simpson, C. \& Schmid, S. M. 1983. An evaluation of criteria to deduce the sense of movement in sheared rocks. Bull. geol. Soc. Am. 94, $1281-1288$.

Speed, R. C. 1983. Structure of the accretionary complex of Barbados, I: Chalky Mount. Bull. geol. Soc. Am. 94, 92-116.

Speed, R. C., Westbrook, G. K. et al. 1984. Lesser Antilles Arc and adjacent terranes. Atlas 10, Ocean Margin Drilling Program, Regional Atlas Series. Marine Science International, Woods Hole.

Stein, S., DeMeta, C., Gordon, R., Brodholt, J., Engeln, J., Wiens, D., Argus, D., Lundgren, P., Stein, C. \& Woods, D. 1987. A test of alternative Caribbean Plate relative motion models. J. geophys. Res. 92.

Sykes, L. R., McCann, W. \& Kafka, A. L. 1982. Motion of Caribbean plate during last 7 million years and implications for earlier Cenozoic movements. J. geophys. Res. 87, 10,656-10,676.
Taira, A., Okada, H., Whitaker, J. \& Smith, A. 1982. The Shimanto Belt of Japan: Cretaceous-Lower Miocene active-margin sedimentation. In: Trench and Forearc Geology: Sedimentation and Tectonics on Modern and Ancient Active Plate Margins (edited by Leggett, J. K.). Spec. Publs geol. Soc. Lond. 10, 5-26.

Valéry, P., Nely, G., Mascle, A., Biju-Duval, B., LeQuellec, P. \& Berthon, J. L. 1985. Structure et croissance d'un prisme d'accrétion tectonique proche d'un continent: la Ride de la Barbade au Sud de'l arc antillais. In: Géodynamique des Caraibes (edited by Mascle, A.). Editions Technip, Paris, 173-186.

von Huene, R. 1979. Structure of the outer convergent margin off Kodiak Island, Alaska, from multichannel seismic records. In: Geological and Geophysical Investigations of Continental Margins (edited by Watkins, J. S. et al.). Mem. Am. Ass. Petrol. Geol. 29, 261-272.

Westbrook, G. K. 1982. The Barbados Ridge Complex: tectonics of a mature forearc system. In: Trench and Forearc Geology: Sedimentation and Tectonics in Ancient and Modern Active Plate Margins (edited by Leggett, J. K.). Spec. Publs geol. Soc. Lond. 10, 275-290.

Westbrook, G. K., Smith, M. J., Peacock, J. H. \& Poulter, M. J. 1982. Extensive underthrusting of undeformed sediment beneath the accretionary complex of the Lesser Antilles Subduction Zone. Nature 300, 625-628.

Westbrook, G. K. \& Smith, M. J. 1983. Long décollements and mud volcanoes: evidence from the Barbados Ridge Complex for the role of high porewater pressures in the development of an accretionary complex. Geology 11, 279-283.

Westbrook, G. K., Mascle, A. \& Biju-Duval, B. 1984. Geophysics and the structure of the Lesser Antilles Forearc. Init. Reps DSDP, Washington (U.S. Govt Printing Office), 78A, 23-38.

White, R. S. \& Louden, K. E. 1983. The Makran continental margin: Structure of a thickly sedimented convergent plate boundary. In: Geological and Geophysical Investigations of Continental Margins (edited by Watkins, J. S. \& Drake, C. L.). Mem. Am. Ass. Petrol. Geol. 34, 499-518. 